\title{
An empirical study on critical success factors for electronic commerce in the Chinese publishing industry
}

\author{
(C) Higher Education Press and Springer-Verlag 2007
}

\begin{abstract}
Critical success factors for electronic commerce (e-commerce) have been a hot topic in both the academe and industry. This paper puts forward hypotheses on success factors for e-commerce of traditional companies first. Then, it conducts an empirical study on the Chinese publishing industry in order to verify the hypotheses. After testing the validity and reliability of the data, this paper verifies the hypotheses with regression analyses, and finally identifies factors impacting e-commerce success such as leadership, strategy, organization, management, IT, customers, comprehensive functions of website and customeroriented functions. In addition, customers, strategy, IT and comprehensive functions of website are identified as the critical factors impacting e-commerce success. This research not only stimulates e-commerce research in China, but also has an instructional effect on the implementation of e-commerce so that Chinese publishing enterprises can increase the success rate of their e-commerce objectives.
\end{abstract}

Keywords electronic commerce, assessment indicators of e-commerce success, impact factors, critical success factors for e-commerce

\section{Introduction}

Electronic commerce (e-commerce) applications are increasingly popular all over the world. E-commerce is an opportunity and challenge for traditional companies.

Translated from Xitong Gongcheng Lilun yu Shijian 系统工程理论与实践 (System Engineering Theories and Practice), 2006, 26(2): 27-35

HUANG Jinghua ( $₫)$, ZHAO Chunjun, LI Jingting

Research Center for Contemporary Management, School of Economics and Management, Tsinghua University, Beijing 100084, China

E-mail: huangjh@em.tsinghua.edu.cn 
Most companies face various difficulties when they try to implement e-commerce. How much benefit would e-commerce bring to an enterprise? What are the factors affecting e-commerce success? How can a company assure the success of e-commerce in view of strategy, management, organization and technologies? How should it assess e-commerce effects? To answer these questions, this paper analyzes the critical success factors (CSF) for traditional companies' e-commerce through an empirical study. Not only does the study strive to enhance e-commerce theories and establish the foundation for CSF, but it also has practical value. Results of the study will form part of the foundation for assessing the effect of e-commerce and provide decision support for enterprises to develop an e-commerce strategy in order to alleviate or avoid the risk of implementation of e-commerce and contribute to e-commerce success.

There are different definitions of e-commerce. Our study defines e-commerce as purchasing, selling, providing services and communicating with customers, suppliers and partners over the Internet.

Research on CSF for e-commerce consists of two parts. One is about the assessment indicators for e-commerce success, which are the indices for measuring the success of e-commerce. The other one is about critical factors affecting e-commerce success.

After reviewing the extant literatures in the above two areas and considering some experts' views, we propose a set of assessment indicators for e-commerce and factors influencing e-commerce. Based on it, we propose a success factors model for the e-commerce of Chinese traditional companies. In order to test the model, we choose the book publishing industry in China as the empirical research sample.

\section{Literature review and limitations of the prior studies}

Research on the CSF for e-commerce remains in its infancy, which evolved from IT/IS/e-commerce value and evaluation and factors influencing IT/IS/ e-commerce.

Numerous researchers have studied IS success from different perspectives. A comprehensive IS success model of an integrated view of the concept of IS success was suggested by DeLone and McLean (1992) (D\&M Model). The model is composed of six success factors such as systems quality, information quality, system usage, user satisfaction, personal benefit and organizational benefit. Many researchers regard Delone and Mclean's work as a major breakthrough. More than 300 papers have validated, challenged, or proposed enhancements to this model. After reviewing these papers, DeLone and McLean (2003) updated the D\&M IS success model. Furthermore, they proposed an e-commerce success model, which 
includes six types of indicators, such as systems quality, information quality, service quality, usage, user satisfaction, and net benefit.

Barua et al. (2001) presented a framework of electronic business value that enumerates linkages between performance drivers, operational excellence and financial metrics. They designed and tested a comprehensive survey instrument, and gathered data from over 1000 organizations. Data provided overall empirical support for the conceptual business value model. The study shows that the drivers have strong impacts on operational excellence measures and that the level of operational excellence influences financial performance.

Chatterjee and Grewal (2002) studied the institutional enablers of the organizational assimilation of web technologies. They verified that top management championship, strategic investment rationale, and extent of coordination are important for the assimilation of the Web within an organization.

Zhu et al. (2003) and his research team have been investigating drivers of e-commerce value in recent years. They compared the differences of e-commerce value across countries. They gathered survey data from 612 firms across ten countries in the financial services industry in order to test the relationship between drivers and e-commerce value. There are several key important findings. First, IT integration emerges as the strongest factor for e-commerce value, while financial resources, firm scope, and regulatory environment also significantly contributed to e-commerce value. Second, firm size is negatively related to e-commerce value, suggesting that structural inertia associated with large firms tends to retard e-commerce value. Third, competitive pressure often drives firms to adopt e-commerce, but e-commerce value originates more from internal organizational resources than from external pressure. Finally, government regulation plays a much more important role in developing countries than in developed countries.

Madeja and Schoder (2002) studied the empirical evidence on the features of corporation web pages that influence e-commerce success. They designed 15 indicators of eight features of a company's website that impact website success. The result shows that six web features have a significant impact on corporation website success, among which two features have significant impacts on B2B websites and four features have significant impacts on B2C websites. Thirteen indicator variables are used to evaluate firm performance such as corporate image, market share, marketing cost, sale cost, new market, sales revenue, new service, customer service, customer satisfaction, customer loyalty, and company's value and so on.

Qiu and Foster (2003) used mature degree index to evaluate e-commerce success in the Chinese electronic industry, and proposed nine aspects of the impact factors, such as type of ownership, enterprise culture, structure of organization, top management support and so on. 
Besides the above literatures, there are many others. Although they are valuable to our research, they have some limitations. Firstly, different researchers have different understandings of e-commerce success and assessment indicators. There are many different categories of assessment indicators of e-commerce success and impact factors (Rai, 2002). Secondly, most of the studies focus on either assessment indicators or impact factors. There are few studies on both aspects and the relationship between them. Thirdly, research methodology of IS/e-commerce success factors is not mature enough in China. Most studies conclude what the e-commerce influence "should" be and some factors "may" influence e-commerce success without quantitative analysis (Wang, Wang and Feng, 2000; Zhong, 2003). Finally, empirical studies conducted by most of the researchers are based on data from countries other than China. Although their findings would be referenced to Chinese firms, they need to be further tested by Chinese samples.

\section{The success factors model for the e-commerce of traditional companies}

Based on the prior research results, we proposed initial assessment indicators of e-commerce success and impact factors. We enquired 26 experts' opinions on the initial indicators and impact factors through two rounds of Delphi survey. Each item (variable) is measured on a five-point Likert scale, which represents five options separately: "extremely important" $(=5)$, "important" $(=4)$, "not sure" (=3), "unimportant" (=2), "extremely unimportant" $(=1)$. Content validity ratio (Lawshe, 1975) is used for selecting the important assessment indicators and impact factors for e-commerce success. These important indicators and factors are the final variables our study use. We also detail the definitions of each category of indicators and factors.

\subsection{Assessment indicators of e-commerce success}

E-commerce is an important instrument for a firm to achieve its strategy. Therefore, e-commerce effect should be measured by the degree of e-commerce support to the enterprise strategy, degree of e-commerce impact on the enterprise, and even the enterprise performance. In other words, whether e-commerce is successful or not should be measured by how much it influences the business performance of a company (Barua, Konana and Whinston, 2001; Madeja and Schoder, 2002). According to the Performance Evaluation System for Chinese Enterprises (Meng, 2002) and Porter's value chain theory, e-commerce success could be assessed by the six types of indicators in the quantitative and qualitative aspects: (1) quantitative 
marketing service indicators; (2)quantitative procurement/collaboration indicators; (3) general quantitative indicators; (4) qualitative marketing service indicators; (5) qualitative procurement/collaborative indicators; and (6) general qualitative indicators. The six types of indicators can be operationalized by the following indicators respectively.

- Marketing cost and sales expenses operationalize quantitative marketing service.

- Supply chain efficiency, procurement cost, and procurement expenses operationalize quantitative procurement/collaboration.

- Revenue per employee, gross profit margin, net profit to operational expenses ratio, and working capital turnover operationalize general quantitative indicators.

- Customer satisfaction and more services to customers operationalize qualitative marketing service.

- Collaboration with partners operationalizes qualitative procurement/ collaboration.

- Corporate image, enterprise value, and market share operationalize general qualitative indicators.

\subsection{Impact factors for e-commerce success}

We study the impact factors from two aspects. One is from internal enterprise factors. The other is from website features.

\subsubsection{Internal enterprise impact factors}

The leadership factor implies top management championship. Top management could offer visions and guidelines to managers in departments and business units about the opportunities and risks in assimilating e-commerce. Their beliefs and active participation serve as powerful signals to the rest of the managerial community (Chatterjee and Grewal, 2002; Zhong, 2003; Esteves and Pasto, 2000; Al-Mashari, 2003; Hartman, 2000; Holland and Light, 1999; Huff and Wade, 2000; Poon and Wagner, 2001; PWC, 2002; Umble, 2003).

E-commerce strategy should support a firm's strategy. Developing and adjusting e-commerce strategy is important for a firm to implement e-commerce (Hartman, 2000).

\footnotetext{
1"The Emm@Framework Supports Comprehensive Risk Management," http://www. pwcglobal.com/extweb/service.nsf/docid/e0763bd8dc558fcb852569810053cba6, February 2002
} 
The management factor implies that an organization should establish an effective management pattern of human resource, financial resource and material resource in e-commerce project implementation. Effective management could make good use of resources and improve the efficiency of e-commerce implementation (Chatterjee and Grewal, 2002; Esteves and Pasto, 2000; Al-Mashari, 2003; Hartman, 2000; Holland and Light, 1999; Huff and Wade, 2000; Poon and Wagner, 2001; PWC, 2002; Umble, 2003; Shi, Chen and Jiang, 2000; Tang, 2000; Weill and Vitale, 2001).

The organization factor is interrelated with structure, culture, employee and innovation, which plays an important role in e-commerce implementation (Hartman, 2000). The organization factor could determine how an enterprise reacts to transformation, makes full use of resources, or adapts to a new environment (Esteves and Pasto, 2000; Al-Mashari, 2003; Hartman, 2000; Holland and Light, 1999; Poon and Wagner, 2001; PWC, 2002; Umble, 2003; Shi, Chen and Jiang, 2000; Tang, 2000; Weill and Vitale, 2001).

The technology factor implies the IT infrastructure. Because e-commerce is the combination of business rules and information technology, enterprises cannot meet the e-commerce implementation requirements without good IT infrastructure. E-commerce success is based on strong and standardized IT infrastructure, which could help accelerate the implementation process of e-commerce applications (Barua, Konana and Whinston, 2001; Al-Mashari, 2003; Hartman, 2000; Tang, 2000; Zhu and Kraemer, 2002).

The customer and supplier factor implies the e-readiness and management level of an enterprise's customers or suppliers. This factor is the most different one from IS success factors. E-commerce not only affects the enterprise itself, but also deals with other organizations, such as suppliers and customers, as well as all kinds of enterprise partners, even its competitors. It is important for an enterprise to establish a close relationship with their suppliers and customers while implementing e-commerce.

The above type of factors can be operationalized by the corresponding variables as shown in Fig. 1.

\subsubsection{Website features and functions}

In an e-commerce system, all users like employees, customers, and suppliers have to obtain information or services and transact business through a corporation's website. It is very important for a website to have enough functions required by users. We classify web features and functions into three constructs, i.e., overall features and functions, functions for customers, and functions for suppliers. These three constructs can be operationalized by the corresponding variables as shown in Fig. 2. 

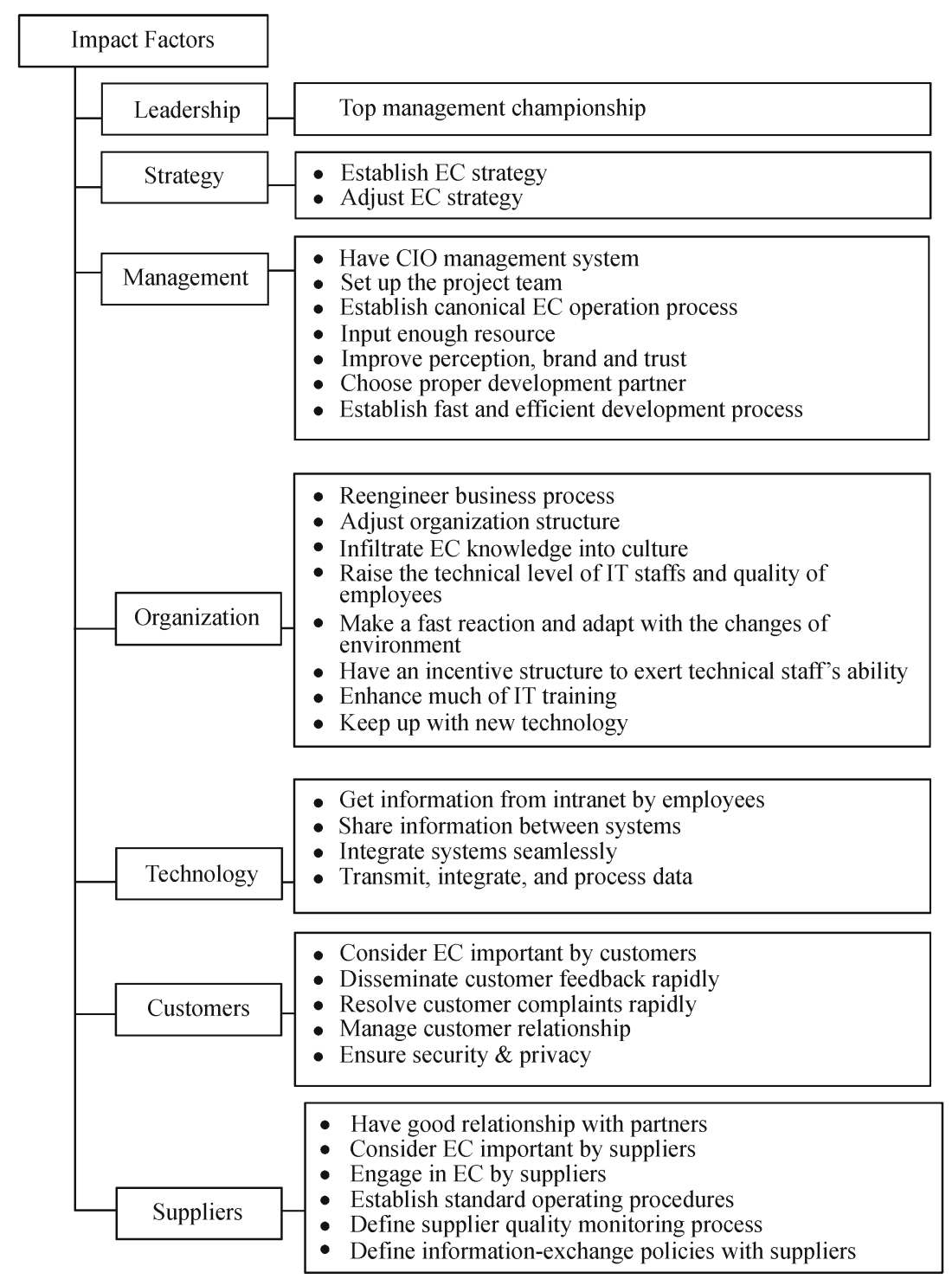

Fig. 1 Internal enterprise impact factors

\subsection{Hypothesis of success factors model for e-commerce}

On the basis of the identified assessment indicators and impact factors, we propose the following hypothesis: leadership, strategy, management, organization, technology, customers and suppliers factors affect e-commerce success; overall 


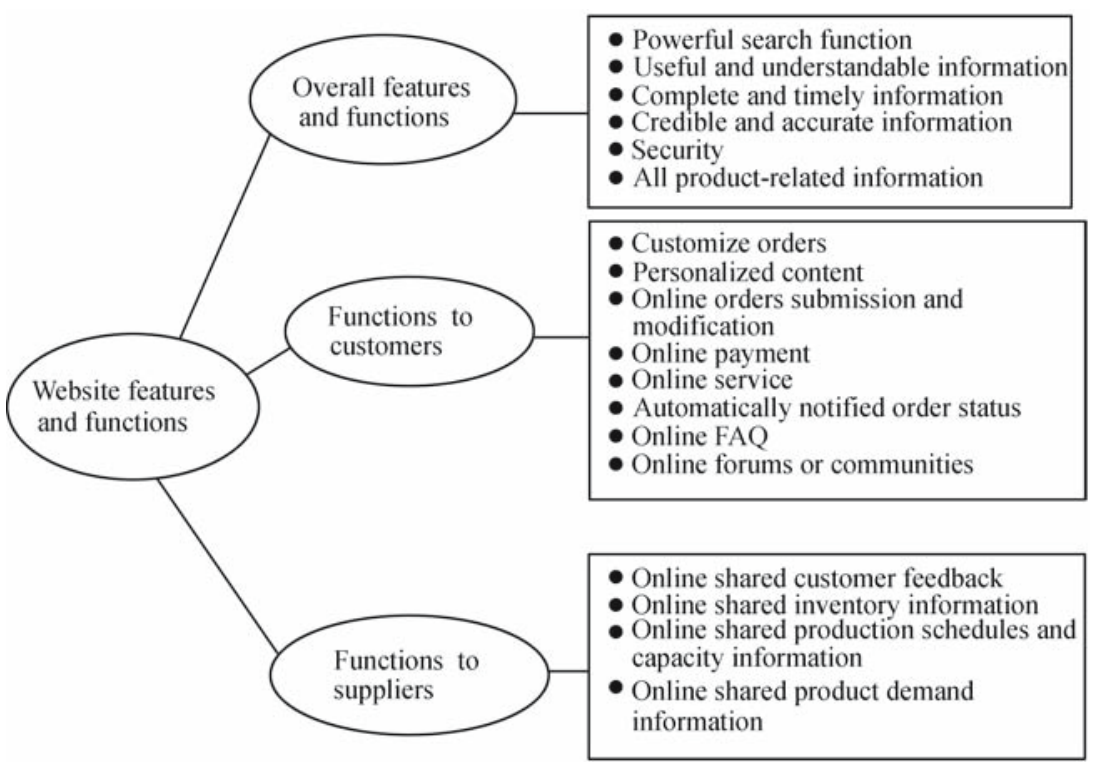

Fig. 2 Website features and functions

website features and functions, functions for customers, and functions for suppliers affect e-commerce success.

\section{Research methodology}

\subsection{Samples and revised hypothesis}

China has become the largest country in the world in terms of its great varieties of books. In recent years, the informationalization and Internet application in the industry have been developing very fast while the size of book publishing is increasing. By April 2004, the number of publishing houses with independent domain name reached $305,53.5 \%$ of 570 houses according to the statistics from the General Administration of Press and Publication of the People's Republic of China. Employees with good educational background use personal computers to work, which establishes a good foundation of management with computers. On the other hand, books, as the top online sales products, inevitably stimulate e-commerce application of publishing houses. Therefore, we choose the book publishing industry as the survey object.

In the publishing industry, e-commerce is defined as trading and sharing information and services with readers, dealers, suppliers, authors and partners 
through the Internet. Before the empirical survey, the questionnaire was pilottested. Using the result of the pilot test, wording of certain items was changed to improve clarity and to minimize ambiguity. A more important finding is that publishing houses in China hardly used the Internet to make deals with their suppliers. Therefore, we exclude some indicators and factors related to suppliers, and revise the hypothesis shown in Fig. 3.

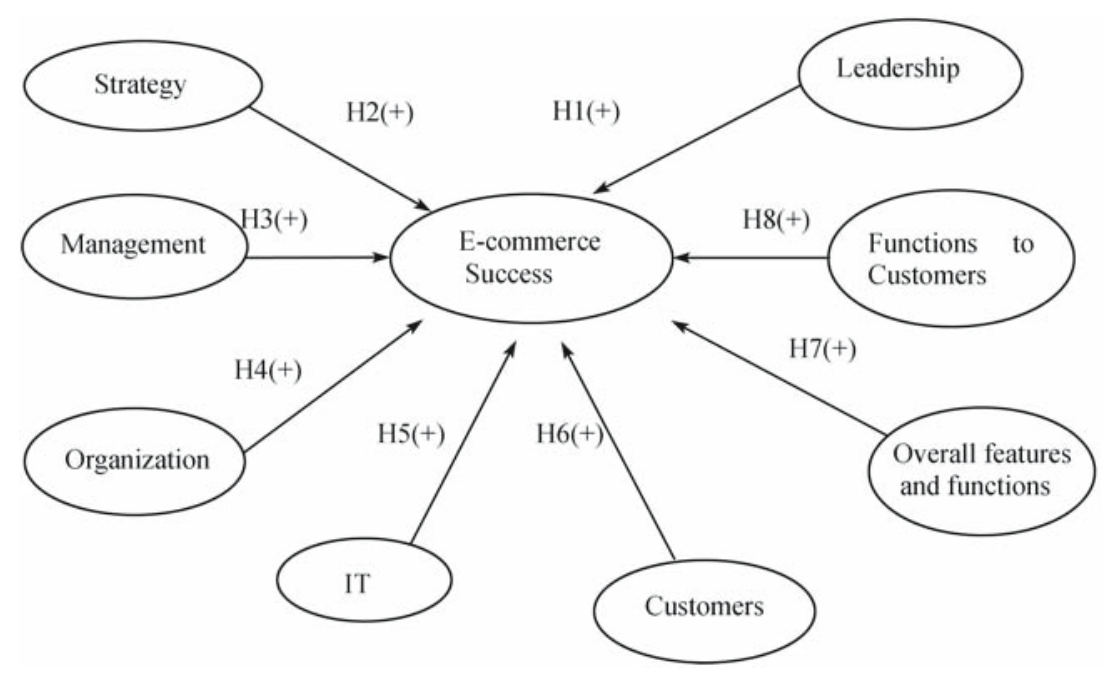

Fig. 3 The revised hypothesis for the book publishing industry

\subsection{Instrument design and sample}

The final revision of the empirical questionnaire consists of three parts: the basic information of a company, assessment indicators for e-commerce success, and impact factors for e-commerce success.

Each question that explores the companies' situation about the indicators and factors is measured on a seven-point Likert scale, ranging from "strongly accord with (=7)" to "strongly disaccord with $(=1)$ ".

From April to August 2004, we sent the questionnaires to the 305 publishing houses that had implemented e-commerce. Ninety-three questionnaires were returned and 84 of them were useable.

\subsection{Statistical analysis}

Statistical analysis of basis data is shown in Table 1. We believe that these 84 samples represent the whole industry. 
Table 1 Statistical analysis of basis information

\begin{tabular}{|c|c|c|}
\hline & Sample & Percentage $(\%)$ \\
\hline \multicolumn{3}{|l|}{ Location } \\
\hline Beijing & 52 & 61.9 \\
\hline Others & 32 & 38.1 \\
\hline \multicolumn{3}{|l|}{ Ownership } \\
\hline State Owned & 79 & 94.0 \\
\hline Others & 5 & 6.0 \\
\hline \multicolumn{3}{|l|}{ History of the company } \\
\hline Before 1980 & 41 & 48.8 \\
\hline After 1980 & 43 & 51.2 \\
\hline \multicolumn{3}{|l|}{ Number of employee } \\
\hline$<50$ & 7 & 8.3 \\
\hline $50-99$ & 20 & 23.8 \\
\hline $100-199$ & 29 & 34.5 \\
\hline $200-299$ & 13 & 15.5 \\
\hline $300-399$ & 5 & 6.0 \\
\hline$>400$ & 10 & 11.9 \\
\hline \multicolumn{3}{|l|}{ Percentage of IT employees } \\
\hline$<1 \%$ & 18 & 21.4 \\
\hline $1 \%-5 \%$ & 58 & 69.1 \\
\hline $5.1 \%-10 \%$ & 6 & 7.1 \\
\hline $10.1 \%-15 \%$ & 2 & 2.4 \\
\hline \multicolumn{3}{|l|}{ Type of the house } \\
\hline Social science & 27 & 32.1 \\
\hline Science and technology & 19 & 22.5 \\
\hline Literature and arts & 5 & 6.0 \\
\hline Education & 5 & 6.0 \\
\hline Children & 4 & 4.8 \\
\hline University & 24 & 28.6 \\
\hline \multicolumn{3}{|l|}{ Website Setup Time } \\
\hline 2003 & 17 & 20.2 \\
\hline 2002 & 12 & 14.3 \\
\hline 2001 & 14 & 16.7 \\
\hline 2000 & 17 & 20.2 \\
\hline Before 2000 & 24 & 28.6 \\
\hline
\end{tabular}

\subsection{Instrument validity and reliability}

Since the indicators and factors are gathered by reviewing related literature and by two rounds of expert surveys, the content validity of the questionnaire is deemed acceptable. We then calculate Cronbach's $\alpha$ to test reliability and use factor analysis to test construct validity. Generally, if Cronbach's $\alpha$ is greater than 0.7 , the instrument is reliable. If eigenvalue is greater than 1 , cumulative variance explained 
is acceptable and if factor loading is greater than 0.5 , the construct is valid (Zhu, Xu and Dedrick, 2003; Zhuang and Lederer, 2003).

In our study, we use SPSS 13.0 as the analysis tool. The analysis results prove that the assessment indicators and the impact factors such as the leadership, strategy, management, organization, technology, customers, and overall features and functions factors can be scaled by the above variables. But for the factor of functions to customers, online payment variable's factor loading is less than 0.5 , which may demonstrate that this variable is not important. In addition, we have done a T-test. The result also shows that online payment does not significantly affect e-commerce success. Hence, we delete the variable of online payment.

\section{Empirical analysis}

\subsection{Simple linear regression analysis}

We suppose that the impact factors do not influence each other, in other words, each factor influences e-commerce success separately.

\subsubsection{Internal enterprise impact factors and e-commerce success}

In the simple linear regression of internal enterprise impact factors and e-commerce success, each factor has a significant effect on e-commerce success (Table 2). Take "customer factor" as an example, $R^{2}=0.32$ means the "customer" factor could explain $32 \%$ of e-commerce success's diversification by itself. Standardized coefficient being 0.566 and the results of the $\mathrm{F}$ test show that this regression model is statistically significant.

\subsubsection{Website features and e-commerce success}

In the simple linear regression of website features and e-commerce success, each factor has a significant effect on e-commerce success (Table 3).

Table 2 Simple linear regression model for internal enterprise impact factors

\begin{tabular}{lccrc}
\hline & $R^{2}$ & Standardized Coefficients & $F$ & Sig. \\
\hline Leadership & 0.100 & 0.317 & 9.135 & 0.003 \\
Strategy & 0.233 & 0.483 & 24.911 & 0.000 \\
Management & 0.262 & 0.512 & 29.151 & 0.000 \\
Organization & 0.254 & 0.504 & 27.953 & 0.000 \\
Technology & 0.227 & 0.476 & 24.083 & 0.000 \\
Customers & 0.320 & 0.566 & 38.650 & 0.000 \\
\hline
\end{tabular}

$p<0.01$ 
Table 3 Simple linear regression model for website features

\begin{tabular}{lcccc}
\hline & $R^{2}$ & Standardized Coefficients & $F$ & Sig. \\
\hline Overall features and function & 0.336 & 0.579 & 41.418 & 0.000 \\
Functions to Customers & 0.172 & 0.414 & 16.989 & 0.000 \\
\hline
\end{tabular}

$p<0.001$

In summary, on the condition that all impact factors do not interactively influence each other, the hypothesis is supported.

\subsection{Multivariate regression analysis}

\subsubsection{Internal enterprise impact factors and e-commerce success}

In practice, the internal enterprise impact factors may influence each other. Therefore, we make the multivariate regression analysis.

We use six factors (leadership, strategy, management, organization, technology and customer) as independent variables and entire e-commerce success as dependent variable in the regression model. The model is as follows

$$
Y=\alpha+\beta_{1} L+\beta_{2} S+\beta_{3} M+\beta_{4} O+\beta_{5} I T+\beta_{6} C+\varepsilon
$$

where, $Y$ represents the entire e-commerce success; $L$ represents the leadership; $S$ represents strategy; $M$ represents management; $O$ represents organization; $I T$ represents information technology, and $C$ represents customers.

The results are shown in Table 4 and Table 5 indicating that this model is not acceptable.

Table 4 Multivariate regression model test

\begin{tabular}{lcccc}
\hline$R^{2}$ & Adjusted $R^{2}$ & Estimated Standard Error & $F$ & Sig. \\
\hline 0.450 & 0.407 & 0.848 & 10.492 & 0.000 \\
\hline
\end{tabular}

Table 5 Multivariate regression model

\begin{tabular}{lcccrc}
\hline & $\begin{array}{c}\text { Unstandardized } \\
\text { Coefficients }\end{array}$ & Standard Error & $\begin{array}{c}\text { Standardized } \\
\text { Coefficients }\end{array}$ & $T$ & Sig. \\
\hline Constance & 1.118 & 0.386 & - & 2.898 & 0.005 \\
Leadership & -0.256 & 0.101 & -0.336 & -2.543 & 0.013 \\
Strategy & 0.193 & 0.114 & 0.264 & 1.698 & 0.094 \\
Management & $2.845 \mathrm{E}-02$ & 0.154 & 0.032 & 0.185 & 0.854 \\
Organization & 0.150 & 0.142 & 0.168 & 1.054 & 0.295 \\
Technology & 0.148 & 0.089 & 0.191 & 1.661 & 0.101 \\
Customers & 0.359 & 0.096 & 0.419 & 3.753 & 0.000 \\
\hline
\end{tabular}

$p<0.1$ 
Furthermore, we use the Backward method to adjust the multivariate regression model and get the model

$$
Y=\alpha+\beta_{1} S+\beta_{2} I T+\beta_{3} C+\varepsilon
$$

The model fit indices (Table 6) and regression coefficients (Table 7) indicate that only strategy, technology and customers have a significant effect on e-commerce success. We denominate them as the critical impact factors.

Table 6 Multivariate regression model test

\begin{tabular}{lcccc}
\hline$R^{2}$ & Adjusted $R^{2}$ & Estimated Standard Error & $F$ & Sig. \\
\hline 0.396 & 0.373 & 0.872 & 17.472 & 0.000 \\
\hline
\end{tabular}

Table 7 Multivariate regression model

\begin{tabular}{lccccc}
\hline & $\begin{array}{c}\text { Unstandardized } \\
\text { Coefficients }\end{array}$ & Standard Error & $\begin{array}{c}\text { Standardized } \\
\text { Coefficients }\end{array}$ & $T$ & Sig. \\
\hline Constance & 0.856 & 0.375 & - & 2.283 & 0.025 \\
Strategy & 0.148 & 0.078 & 0.201 & 1.898 & 0.061 \\
IT & 0.157 & 0.081 & 0.203 & 1.941 & 0.056 \\
Customers & 0.306 & 0.094 & 0.357 & 3.269 & 0.002 \\
\hline
\end{tabular}

$p<0.1$

Model 2 is different from Model 1. In Model 1, there are six independent variables, and some coefficients are not significant, while in Model 2 there are three independent variables-strategy, IT, and customers, which affect the dependent variable-e-commerce success-significantly $(p<0.1)$. Do the independent variables-leadership, management, and organization affect e-commerce when all internal enterprise impact factors exist at the same time? To answer this question, we explored multi-collinearity among all the internal enterprise impact factors through regression analysis of independent variables. We found that there exists collinearity among strategy, leadership, management and organization. With the method of deleting variables to solve the collinearity, we canceled leadership, management and organization variables from Model 1 to get Model 2.

Therefore, when the factors of leadership, strategy, management, organization, IT and customers affect e-commerce success together, the factors of strategy, IT and customers influence more on e-commerce success than other factors do due to the collinearity of all the factors. The factors of strategy, IT and customers are identified as the critical factors for e-commerce success. 


\subsubsection{Website features and e-commerce success}

Like the internal enterprise impact factors, two factors of website features may influence each other. Therefore, we make the multivariate regression analysis.

We suppose the multivariate regression model as

$$
Y=\alpha+\beta_{1} O F+\beta_{2} C F+\varepsilon
$$

where, Y represents the entire e-commerce success; OF represents the overall features and functions; CF represents functions to customers.

The results are shown in Table 8 and Table 9. But this model is not acceptable because the factor of functions to customers is not significant. Then, we delete this factor. The result is the same as simple linear regression (as shown in Table 3).

When we explored the collinearity between the factor of overall features and function and the factor of functions to customers, we found that they are collinear. But the factor of functions to customers influences e-commerce success more than the other one does. The former is the critical factor for e-commerce success.

Table 8 Multivariate regression model test

\begin{tabular}{lcccc}
\hline$R^{2}$ & Adjusted $R^{2}$ & Estimated Standard Error & $F$ & Sig. \\
\hline 0.346 & 0.330 & 0.902 & 21.45 & 0.000 \\
\hline
\end{tabular}

Table 9 Multivariate regression model

\begin{tabular}{lccccc}
\hline & $\begin{array}{c}\text { Unstandardized } \\
\text { Coefficients }\end{array}$ & Standard Error & $\begin{array}{c}\text { Standardized } \\
\text { Coefficients }\end{array}$ & $T$ & Sig. \\
\hline $\begin{array}{l}\text { Constance } \\
\begin{array}{l}\text { Overall features } \\
\text { and function }\end{array}\end{array}$ & 0.957 & 0.402 & - & 2.382 & 0.020 \\
$\begin{array}{l}\text { Functions to customers } \\
\text { pund }\end{array}$ & 0.119 & 0.096 & 0.508 & 4.651 & 0.000 \\
$p<0.1$ & & 0.104 & 0.125 & 1.149 & 0.254 \\
\hline
\end{tabular}

\section{Conclusion}

Drawing upon the literature review and expert survey, this paper proposes a success factors model for e-commerce of traditional companies. A questionnairebased empirical study in the Chinese book publishing industry was conducted to test this model. Survey data were collected from 93 book publishing houses. As indicated by the results of data analysis, the questionnaire was valid and reliable. Then, we tested the causal relationship between dependent variables and 
independent ones by using the methods of regression analysis. The empirical analysis demonstrated that the factors of leadership, strategy, management, organization, IT, customers, overall features and functions of website, and functions for customers have a significant influence on e-commerce success, respectively. Furthermore, it suggests that the factors of customers, strategy, IT and overall features and functions of a website are the critical success factors for e-commerce.

The above findings are usable for Chinese publishing houses. First, e-commerce in China's publishing industry just began to expand in recent years. A suitable e-commerce strategy is very important for a publishing house to achieve ecommerce success. Furthermore, houses should maintain flexibility, which means that they need to be ready to make radical shifts in their e-commerce strategy. Second, Chinese publishing houses are changing from product-centered to customer-centered. E-commerce is regarded as the important channel for providing information and services to customers. Therefore, how to manage customer relationship through e-commerce is a critical problem for them. Third, IT infrastructure is very important for e-commerce success. Chinese publishing companies should enhance their internal IS/IT application; especially integrate "island" subsystems to share information within a company. Finally, publishing houses should improve their website functions and features, especially empower the search function, make information on the website useful and understandable, complete and timely, credible and accurate and so on.

There are some key contributions of this study. First, concerning that e-commerce is different from one industry to another, the empirical study is conducted within a specific industry, assuring the conclusions to be fairly pertinent. Second, in China, it is the first time for this kind of study to carry out a questionnaire-based survey on theoretical problems in the field of e-commerce. This initial investigation can contribute to related research by other scholars in the future. Third, the findings of this study provide the publishing industry with important guidance for improving e-commerce, such as changing from product-oriented to customer-oriented, developing and adjusting e-commerce strategy, improving the IT infrastructure of internal organizations and their website development. In addition, some conclusions of this paper are consistent with those of foreign researchers, while some are only applicable to China, which indicates that e-commerce of Chinese companies has its unique features while sharing certain characteristics with those of international companies. For instance, Barua et al. presented that customer-related processes and customer readiness have an impact on e-commerce value (Barua, Konana and Whinston, 2001), which is consistent with our finding that the factor of customers is critical to e-commerce success. Chatterjee and Grewal (2002) found that top management championship, strategic investment rationale and extent of coordination have significant influence on e-commerce, which is partially 
consistent with our paper's finding that of these three factors only the factor of strategy is significant. Zhu et al. (2003) found that information technology has significant influence on e-commerce value, which is completely consistent with our study's finding. Madeja and Schoder (2002) found that information richness, immediacy and ease of use are more important than other features such as personalization and online forum, which is also consistent with our finding that the overall features of websites are important to e-commerce success.

However, this research is subject to some limitations. Firstly, since the samples are collected from publishing companies, whether the success factors model for e-commerce in other industries is similar or dissimilar to the publishing industry needs further research. Now, our research group is conducting an empirical study in the Chinese banking and high-tech industries, and we will compare the success factors among different industries. Secondly, the history of e-commerce implementation is still brief in China, so the result of the empirical study is limited in terms of time. Therefore, further study is needed to be a valuable extension to the current research.

Acknowledgements This work was partly supported by the National Natural Science Foundation of China (70472007, 70231010, and 70321001), and MOE Project of Key Research Institute of Humanity and Social Sciences at Universities (06JJD630014).

\section{References}

Al-Mashari M (2003). Enterprise resource planning: a taxonomy of critical factors. European Journal of Operational Research, 146(2): 352-364

Barua A, Konana P, Whinston A B, Yin F (2001). Driving e-business excellence. Sloan Management Review, 43(1): 36-45

Chatterjee D, Grewal R (2002). Shaping up for e-commerce: institutional enabler of the organizational assimilation of web technologies. MIS Quarterly, 26(2): 65-89

DeLone W H, McLean E R (1992). Information systems success: the quest for the dependent variable. Information Systems Research, 3(1): 60-95

DeLone W H, McLean E R (2003). The DeLone and McLean model of information systems success: a ten-year update. Journal of Management Information Systems, 19(4): 9-30

Esteves J, Pasto J (2000). Towards the unification of critical success factors For ERP implementations. In: Proceedings of the 10th Annual Business Information Technology (BIT) Conference. Manchester: Manchester Metropolitan University

Hartman A (2000). Net Ready: Strategies for Success in the Economy. New York: McGraw-Hill

Holland C P, Light B A (1999). Critical success factors model for ERP implementation. IEEE Software, 16(3): 30-36

Huff S L, Wade M (1975). Cases in Electronic Commerce. Boston: Irwin/ McGraw-Hill

Lawshe C H (1975). A quantitative approach to content validity. Personnel Psychology, 28(4): 563-575 
Madeja N, Schoder D (2002). Designed for success-empirical evidence on features of corporate web pages. In: Proceedings of the 36th Hawaii International Conference on Systems Science. Hawaii: IEEE

Meng Jianming (2002). Performance Evaluation for Chinese Enterprises. Beijing: China Finance and Economy Publishing House (in Chinese)

Poon P, Wagner C (2001). Critical success factors revisited: success and failure cases of information systems for senior executives. Decision Support Systems, 30(4): 393-418

Qiu Changbo, Forster W (2003). Research on the effect factors of e-commerce application in electronics industry. Intelligence Science, 12(9): 919-921 (in Chinese)

Rai A (2002). Assessing the validity of IS success model: an empirical test and theoretical analysis. Information Systems Research, 13(1): 50-69

Shi Yun, Chen Guoqing, Jiang Zhenhui (2000). Key factors for information technology management. Chinese Journal of Management Science, 8(3): 63-69 (in Chinese)

Tang S M (2000). An impact model of intranet adoption: an exploratory and empirical research. The Journal of System and Software, 51(3): 157-173

Umble H (2003). Enterprise resource planning: implementation procedures and critical success factors. European Journal of Operational Research, 146(2): 241-257

Wang Yingluo, Wang Kanliang, Feng Gengzhong (2000). The actualities and shortages of the studies of e-business's impact on management in China. China Soft Science, (1): 23-26 (in Chinese)

Weill P, Vitale M R (2001). Place to Space: Migrating to E-Business Models. Boston: Harvard Business School Press

Zhong Yuansheng (2003). The development of management research on electronic commerce in China. The World of Management, (11): 135-138 (in Chinese)

Zhu K, Kraemer K (2002). E-commerce metrics for net-enhance organizations: assessing the value of E-Commerce to firm performance in the manufacturing sector. Information Systems Research, 13(3): 275-295

Zhu K, Xu S, Dedrick J (2003). Assessing drivers of e-business value: results of a cross-country study. In: Twenty-fourth International Conference on Information Systems. Seattle: Washington State University, 181-193

Zhuang Y, Lederer A L (2003). An instrument for measuring the business benefits of e-commerce retailing. International Journal of Electronic Commerce, 7(3): 65-99 